\title{
Gyermekkori csuklótáji törések diagnosztikája ultrahanggal
}

\author{
Varga Marcell dr. ${ }^{1}$ - Gáti Nikolett dr. ${ }^{1}$ - Kalóz Erika dr. ${ }^{1}$ \\ Bíró Zsuzsanna dr. ${ }^{1}$. Szeverényi Csenge dr. ${ }^{2}$ \\ Kardos Dániel dr. ${ }^{3}$ - Józsa Gergő dr. ${ }^{3}$
}

\begin{abstract}
${ }^{1}$ Péterfy Sándor Utcai Kórház-Rendelőintézet, Baleseti Központ, Gyermektraumatológiai Osztály, Budapest
${ }^{2}$ Debreceni Egyetem, Általános Orvostudományi Kar, Klinikai Központ, Ortopédiai Klinika, Debrecen

${ }^{3}$ Pécsi Tudományegyetem, Általános Orvostudományi Kar, Gyermekgyógyászati Klinika, Manuális Tanszék, Sebészeti Osztály, Pécs
\end{abstract}

\begin{abstract}
Bevezetés és célkitüzés: Prospektív tanulmányunk célja a gyermekkori csuklótörések ultrahang-diagnosztikájának ismertetése és két mozgásszervi centrum eredményének bemutatása.

Módszer: 2011 januárja és 2015 decembere között 467, 1-15 év közötti gyermek ultrahangvizsgálatát végeztük el. Valamennyi gyermek zárt sérülést szenvedett el és nyitott epiphysisfugával rendelkezett. Az ultrahangvizsgálatot rezidensek és ortopéd-traumatológus, illetve gyermeksebész szakorvosok végezték közvetlenül az elsődleges fizikális vizsgálatot követően, 7-14 MHz frekvenciatartományú lineáris transzducerekkel. Az eredményeket hagyományos kétirányú csukló-röntgenfelvételekkel hasonlítottuk össze.

Eredmények: 97\%-os szenzitivitást és 96\%-os specificitást találtunk. Elmozdulással és komolyabb klinikai konzekvenciával járó törések ultrahanggal is mind felismerésre kerültek.

Következtetés: A mozgásszervi ultrahangvizsgálat a gyermekkori csuklótáji törések igazolásának vagy kizárásának rendkívül hatékony eszköze a napi gyakorlatban.
\end{abstract}

Orv Hetil. 2017; 158(24): 944-948.

Kulcsszavak: ultrahang, gyermekkor, csuklótörés

\section{Ultrasonographic diagnosis of distal pediatric forearm fractures}

Introduction and aim: The aim of our prospective study was to evaluate the effectivity of sonographic diagnosis of pediatric wrist fractures and analyzing the results of two pediatric musculoskeletal centers.

Method: Between 2011 January and 2015 December 467 children aged 0-15 with closed wrist injuries and open growth plates were sonographically and radiologically evaluated by an orthopaedic surgeon or a resident in trainee. Sonography was performed immediately after physical examination with linear probes of 7-14 Mhz frequency. Results were compared to conventional two plane wrist $\mathrm{x}$-rays.

Results: We found 97 sensitivity and 96 specificity of the sonographic evaluation. Fractures with dislocations and more serious clinical consequences were never missed.

Conclusion: Musculoskeletal ultrasound is a very effective tool in daily routine for diagnosing or excluding pediatric wrist fractures.

Keywords: sonography, pediatric, wrist fracture

Varga M, Gáti N, Kalóz E, Bíró Zs, Szeverényi Cs, Kardos D, Józsa G. [Ultrasonographic diagnosis of distal pediatric forearm fractures]. Orv Hetil. 2017; 158(24): 944-948.

(Beérkezett: 2017. március 21.; elfogadva: 2017. április 13.) 
A csuklótáji törések világszerte a gyermekkor leggyakoribb sérülései közé tartoznak, illetve növekvő tendenciát mutatnak [1-4].

A Péterfy Sándor Utcai Kórház-Rendelőintézet és Baleseti Központ Gyermekambulanciáján évente mintegy 1500 gyermek ambuláns vizsgálata történik csuklótáji sérülés miatt. A pontos diagnózis felállítása az esetek túlnyomó részében röntgen- (RTG-) képalkotással történik $[4,5]$. A hagyományos kétirányú RTG-felvétel elhanyagolható egészségügyi kockázatot jelent, ugyanakkor világszerte hangsúlyozott törekvés az ionizáló sugárzás lehetőség szerinti minimalizálása $[6,7]$.

Az utóbbi években számos közlemény jelent meg a gyermekkori csuklótáji törések „point of care” ultrahangos (UH-) diagnosztikájáról [8-12]. A legtöbb szerző egyetért abban, hogy a módszerrel nemcsak a törés ténye, hanem konfigurációja és elmozdulásának mértéke is a RTG-vizsgálatokkal lényegében egyező effektivitással értékelhető [13].

Magyarországon - tudomásunk szerint - gyermekkori törésdiagnosztika céljából ultrahangot rutinszerúen, elfogadott protokoll szerint sehol nem alkalmaznak, illetve magyar nyelvű beszámoló ilyen irányú alkalmazásról eddig nem jelent meg.

A Péterfy Sándor Utcai Kórház-Rendelőintézet és Baleseti Központ Gyermektraumatológiai Osztályán 2011, a Pécsi Tudományegyetem Gyermeksebészeti Centrumában 2014 óta végzünk gyermekkori ultrahangos törésdiagnosztikát.

Prospektív tanulmányunk célja a módszer ismertetése és a két mozgásszervi centrum eredményének bemutatása.

\section{Betegek és módszer}

Vizsgálatunk során a gyermekeket - az ambulanciára való beérkezésüket követően, a primer fizikális vizsgálattal egy időben - lineáris fejjel ellátott ultrahangkészülékkel is megvizsgáltuk. A vizsgálatok során összesen három különböző típusú ultrahangkészüléket használtunk. A lineáris fejek frekvenciatartománya 7-14 MHz-ig terjedt.

A két gyermektraumatológiai centrumban 2011. december és 2015. december között 467 dokumentált esetben végeztünk UH-diagnosztikát. A vizsgálatokat a két intézetben összesen hat orvos végezte (két ortopédtraumatológus szakorvos, két ortopéd-traumatológus szakorvosjelölt, egy gyermeksebész szakorvos, valamint egy gyermeksebész rezidens) „point of care” módon, azaz közvetlenül a fizikális vizsgálatot követően, a RTGfelvételek elkészülése előtt.

A vizsgálatba csak olyan gyermekeket vontunk be, akiknél a fizikális vizsgálat és a klinikum alapján kizárólag kétirányú csuklófelvétel indikációja állt fenn. Kizárólag nyitott növekedési porcok mellett értékeltük az eredményeket. Kizártuk a vizsgálatból azokat az eseteket, ahol a fájdalom nem pontos lokalizációja, a kooperáció hiánya vagy az anamnézis alapján egyéb testtájék RTG-vizsgálata is szükségessé vált (os scaphoideum törése miatt négyirányú felvétel, alkartörés gyanúja miatt alkar-RTG-felvétel stb.).

A vizsgálat háton fekve vagy ülő pozícióban történt. $\mathrm{Az}$ érintett végtagot a gyermek hasára vagy az előtte lévő vizsgálóasztalra helyeztük (1. és 2. ábra).

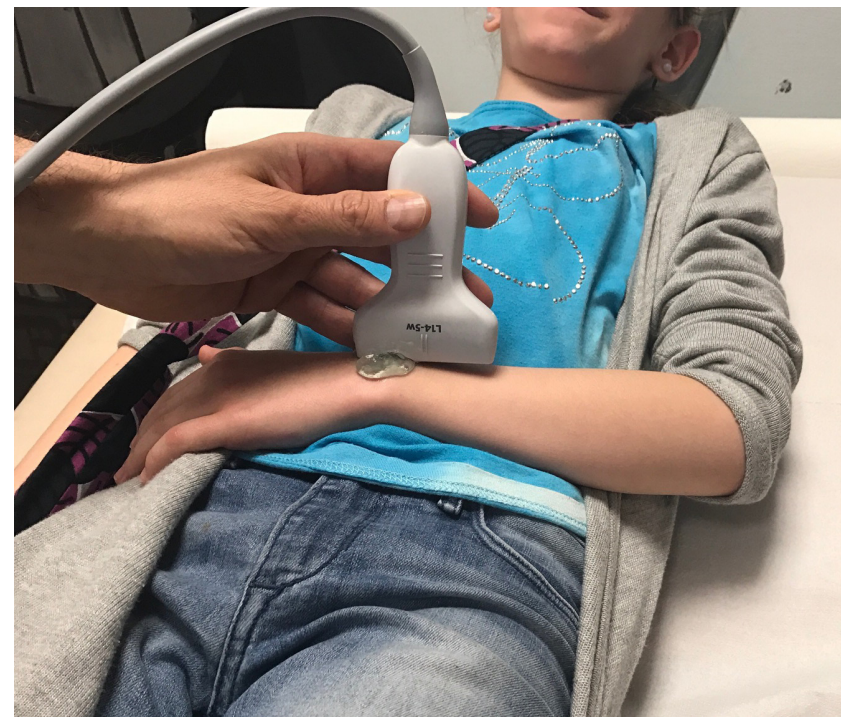

1. ábra | Háton fekvő gyermek csuklósérülésének vizsgálata ultrahanggal

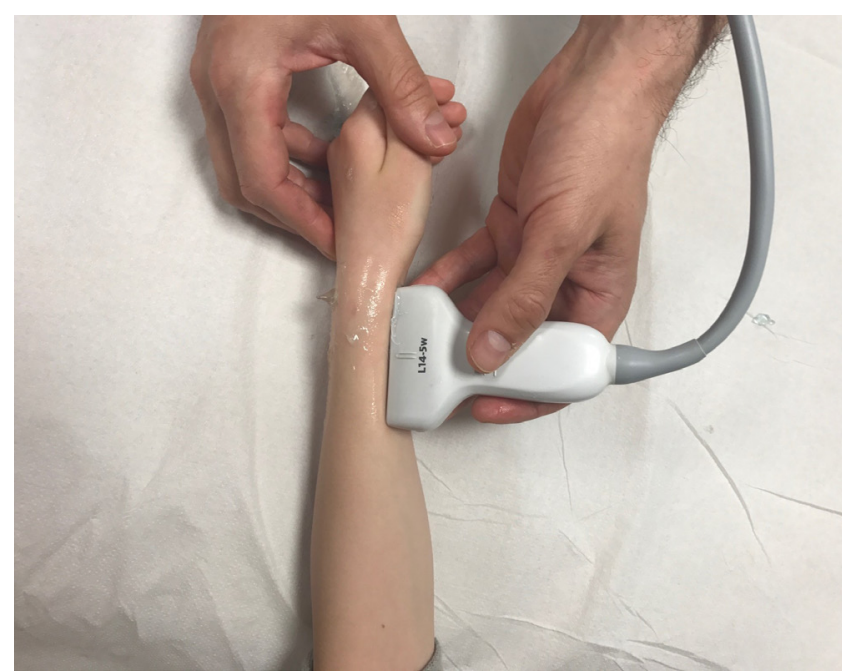

2. ábra

| Transzducertartás ventralis radialis síkban

A transzducerrel hat különböző, a végtag tengelyével megegyező, longitudinális síkban jártuk körül a csuklót, így egy dorsoulnaris, dorsoradialis, lateroradialis, medioulnaris és két ventralis leképezést nyertünk (3. ábra).

Az ellátás ezután a hagyományos protokoll szerint (kétirányú csukló-röntgenfelvétel) folytatódott.

Az ultrahang- és fizikális vizsgálat által felállított diagnózis pontosságát a RTG-felvételekkel összevetve értékeltük (4. és 5. ábra). 


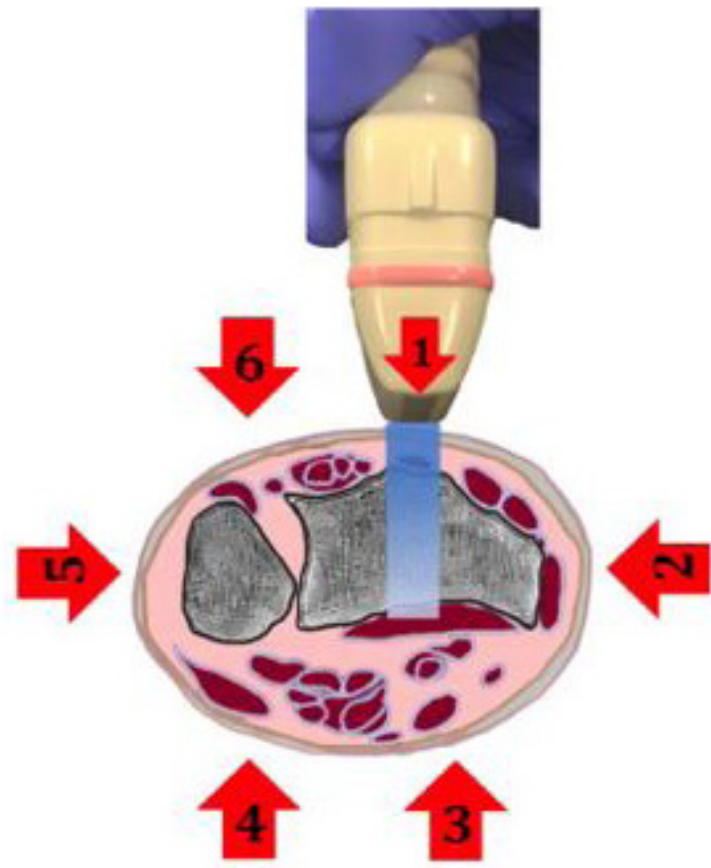

3. ábra $\quad \mid$ A transzducer által leképzett síkok sémás ábrája

A vizsgálatok eredményeinek pontos feldolgozásához egy értékelőlapot szerkesztettünk. A lapon a vizsgáló személy - a beteg adatainak kitöltése után - a primer vizsgálatot követően bejelölte, hogy a klinikum és az ultrahangvizsgálat alapján véleményez-e törést, ha igen, milyen jellegưnek ítélte meg azt. A RTG-felvétel elkészültét követően felvezetésre került a klinikus által a röntgen alapján véleményezett diagnózis. A radiológus által kiadott lelet szintén felvezetésre került, így a vizsgálati eredményeket objektíven tudtuk összehasonlítani.

A fenti kritériumoknak megfelelően 467 esetet értékeltünk.

\section{Eredmények}

$270(57,8 \%)$ esetet a primer RTG alapján pozitívnak, 197-et $(42,2 \%)$ negatívnak találtunk. Ultrahangvizsgálattal 263 esetet értékeltünk pozitívnak és 204-et negatívnak (1. táblázat).

1. táblázat |A RTG- és UH-vizsgálattal értékelt pozitív és negatív esetek megoszlása $(n=467)$

\begin{tabular}{lll}
\hline & RTG & UH \\
\hline Pozitív & 270 & 263 \\
Negatív & 197 & 204 \\
\hline
\end{tabular}

Az észlelt töréseket a klinikai konzekvenciát illetően (konzervatív kezelés, repozíciós igény, mútéti igény) három csoportba osztottuk. Az álnegatív és álpozitív esetek megoszlását az egyes csoportokon belül is vizsgáltuk ( 2 . táblázat).
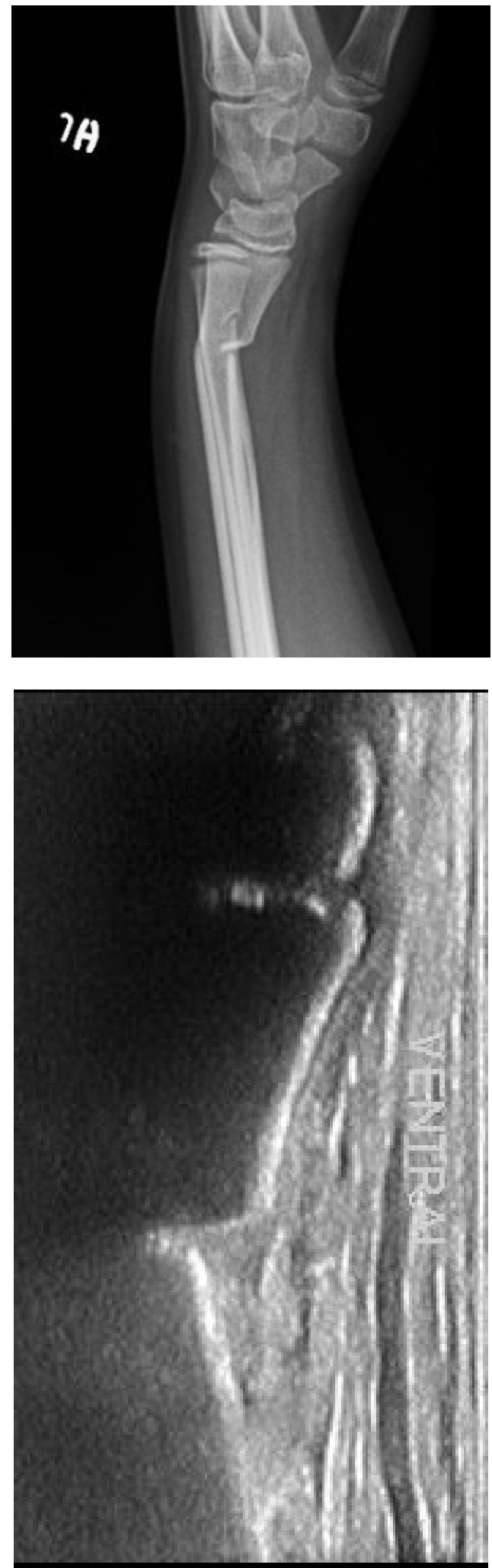

4. és 5. ábra | Oldalirányú csukló-RTG- és ennek megfelelő UH-felvétel

Az álnegatív eseteket, amikor ultrahanggal nem sikerült a RTG-felvételeken látható törést igazolni $(\mathrm{n}=7)$, az elmozdulás nélküli, klinikai konzekvenciával nem járó csoportokban észleltük. Álpozitív eredményeket, amikor az ultrahanggal törésnek véleményezett törés RTG-fel- 
Az álpozitív és álnegatív ultrahangos esetek megoszlása az egyes klinikai csoportokon belül

\begin{tabular}{llll}
\hline $\begin{array}{l}\text { Az észlelt törések felosztása klinikai } \\
\text { konzekvencia alapján, } \mathrm{n}=270\end{array}$ & $\begin{array}{l}\mathrm{RTG} \\
\text { pozitív }\end{array}$ & $\begin{array}{l}\mathrm{UH} \\
\text { álnegatív }\end{array}$ & $\begin{array}{l}\mathrm{UH} \\
\text { álpozitív }\end{array}$ \\
\hline $\begin{array}{l}\text { Csekély klinikai konzekvenciával } \\
\text { járó esetek, átmeneti rögzítést, } \\
\text { fájdalomcsillapítást, gipszet vagy } \\
\text { rögzítő brace-t igénylö } \\
\text { torustörések és elmozdulás nélküli } \\
\text { metaphysistörések }\end{array}$ & $\begin{array}{l}\mathrm{n}=188 \\
(70 \%)\end{array}$ & $\mathrm{n}=7$ & $\mathrm{n}=7$ \\
\hline $\begin{array}{l}\text { Helyi érzéstelenítésben vagy } \\
\text { narkózisban való helyretételt, } \\
\text { gipszrögzítést igénylő }\end{array}$ & $\begin{array}{l}\mathrm{n}=52 \\
(20 \%)\end{array}$ & 0 & 0 \\
$\begin{array}{l}\text { szöglettöréssel járó } \\
\text { metaphysistörések a csontcorticalis } \\
\text { folytonosságával }\end{array}$ & & & \\
\hline $\begin{array}{l}\text { Mütéti ellátást igényló, } \\
\text { a periosteum-szakadással járó nagy } \\
\text { fokban elmozdult törések }\end{array}$ & $\begin{array}{l}\mathrm{n}=30 \\
(11 \%)\end{array}$ & 0 & 0 \\
\hline
\end{tabular}

vételen nem igazolódott $(\mathrm{n}=7)$, szintén csak ebben a csoportban találtunk. A fentiek alapján a szenzitivitást 97\%-nak, a specificitást 96\%-nak találtuk.

Három, primeren álpozitív esetben a nem szűnő fájdalmak miatt később végzett ismételt RTG-vizsgálat callusképződést igazolt, emiatt ezeket utólag pozitívnak minősítettük.

A diagnosztikát végző személyek hatékonysága között szignifikáns különbséget nem találtunk. A RTG- és UHvizsgálattal észlelt 14 ellentmondó diagnózist a tanulási fázis elején, az első 100 eset során állították fel.

\section{Megbeszélés}

A gyermekkori csuklótáji törések diagnózisát, illetve a további terápiás terv felállítását hagyományosan RTG alapján végezzük. A RTG-vizsgálattal igazolható a törés, epiphyseolysis ténye, tengelyeltérésének mértéke [14, 15]. További terápiás tervet a gyermek korának, az elmozdulás mértékének figyelembevételével állítjuk fel.

Gyermekkori ultrahangos törésdiagnosztikát rutinszerüen kevés helyen végeznek a világon. Ennek szervezési, szakmai és anyagi okai is lehetnek - a gyermeksérültek elsődleges ellátása világszerte más-más rendszer alapján történik. A sürgősségi osztályok személyi és tárgyi felszereltsége is jelentős különbséget mutat [16, 17].

A sikeres diagnosztikához gyermektraumatológiában és musculoskeletalis szonográfiában is jártas szakember szükséges. A módszer előnyei ugyanakkor egyértelmúek. Gyors, a beteg számára fájdalmatlan, noninvazív és talán a legfontosabb, hogy ionizáló sugárzással nem jár [8-13, $17,18]$.

Vizsgálataink és a nemzetközi irodalom alapján ultrahanggal a terápiás konzekvenciával járó törések jelenléte, illetve hiánya egyértelműen detektálható és a RTG-nel csaknem megegyező objektív információ nyerhető [8$13,19]$.

Az ultrahangos törésvizsgálat lehetőségét a régió gyermekkori sajátosságai teremtik meg. Tizennégy éves kor alatt, illetve nyitott növekedési porcok mellett a felnőttkorra jellemző ízületi lépcsőképződéssel járó, illetve öszszetett darabos distalis radiustörések nagyon ritkák. A típusos gyermekkori csuklótáji törések (epiphyseolysisek, metaphysis-, torustörések stb.) konfigurációja jellegzetes, a csontcorticalis megváltozásának típusos képével jár.

\section{A vizsgálati technikáról}

A lineáris transzducer által kibocsátott, a csontról teljes egészében visszaverődő ultrahangnyalábok által képzett rajzolat, az adott sík csontcorticalis vonalát a röntgenhez hasonlóan jeleníti meg. Különbség, hogy míg a RTGfelvételen szummációs képet látunk, az UH által alkotott kép mindig a transzducer vastagságának megfelelő területről mutat egy szeletet. Ezért fontos, hogy a vizsgálófejet mindig merólegesen, billentés nélkül helyezzük a csontok hossztengelyére, hogy a képalkotás pontos legyen. A klinikai gyakorlatban a hat standard sík alkalmazása (radiodorsalis, ulnodorsalis, ulnoulnaris, radioradialis, radiopalmaris és ulnopalmaris) elegendő, bár elméletben a csuklót a transzducerrel körbejárva korlátlan számú szelet leképezhető. További különbség, hogy a dorsalis, illetve palmaris irányból felhelyezett transzducer az oldalirányból készült, az ulnaris, illetve radialis irányból képzett szonográfiával pedig az ap. RTG-felvétellel nyerünk analógiába vonható képet (2. ábra). A vizsgálat során a gyermekek karját csak minimálisan kell mobilizálni, ez az alkar és a csukló egyidejü rögzítésével minden esetben probléma nélkül kivitelezhető.

Vizsgálatainkban „hagyományos”, alacsonyabb felbontású fejet $(7 \mathrm{MHz}$ ) és „high resolution”, magas felbontású transzducert $(14 \mathrm{MHz})$ is használtunk. Bár a magas felbontású fejekkel értelemszerúen részletgazdagabb kép nyerhető, a distalis radius- és ulnatörések diagnosztikai hatékonyságának tekintetében nem találtunk különbséget a gépek között. A nagy elmozdulással, teljes periosteum-átszakadással járó, általában operatív indikációt jelentő esetek ultrahangos pontos értékelése nehezebb, ilyenkor a szonográfiás kép alapján a törés ugyan egyértelmúen megállapítható, de annak pontos konfigurációjára nehéz következtetni. Ugyanakkor tapasztalataink azt mutatják, hogy a megfelelő gyakorlat megszerzését követően a diagnosztikai hatékonyság is növekszik.

A tévesen felállított diagnózisoknak (álpozitív, illetve álnegatív esetek) a terápiára kiható érdemi konzekvenciája elméletileg nincs, mivel gyakorlatunk alapján a végtag rögzítése (gipszsín, brace) még töréssel nem járó csuklóés alkarsérülések esetében is indokolt a gyermek panaszai függvényében, és kontrollvizsgálattal az ilyen esetek kiszürhetőek.

Érdemi terápiát igénylő, elmozdulással járó esetek vizsgálata során nem találtunk különbséget az ultrahang- 
és a röntgendiagnosztika hatékonysága közt. Az eltérő diagnózisok az első 100 esetszám során születtek, így az eljárás „tanulási görbéjének” szerepe sem elhanyagolható.

Figyelemre méltó, hogy három betegnél az ultrahangvizsgálattal a klinikus törést diagnosztizált, míg a primer röntgen negatívnak bizonyult. Mivel ezeknek a gyermekeknek elhúzódó panaszai voltak, ismételt RTG-vizsgálatot végeztünk. A négy héttel később készült RTGfelvételen periostealis callus ábrázolódott, amely egyértelmúen korábban lezajlott okkult törésre utal. Ezek alapján feltételezhető, hogy bizonyos esetekben az ultrahang- a röntgenvizsgálatnál szenzitívebb is lehet.

Elvileg differenciáldiagnosztikai problémát jelenthetnek a patológiás (például juvenilis ciszta) alapon kialakuló törések. Bár a vizsgált betegek között ilyen jellegú elváltozás nem fordult elő, feltételezzük, hogy a csontcorticalis felfújt szerkezetének, illetve az esetleges lágyrész-folyamat jelenlétének egyértelmúen fel kell hívnia a figyelmet a további képalkotás (CT, MRI stb.) szükségességére.

\section{Következtetés}

Megfelelő helyi, tárgyi és személyi feltételek megléte esetén (rendelkezésre álló UH-készülék, amelynek segítségével a vizsgálat a primer fizikális vizsgálattal egy időben és egy helyen elvégezhető, gyermektraumatológiai ellátásban jártas szakember mozgásszervi ultrahangkezelési ismeretekkel) a fenti módszer segítségével az ellátás gyorsasága és hatékonysága jelentősen növelhető. Az irodalomban fellelhető tanulmányok hasonló eredményekről számolnak be, ugyanakkor nagy esetszámú feldolgozást keveset találtunk [13].

Hangsúlyozni szeretnénk, hogy tanulmányunkkal nem azt szándékoztuk sugallni, hogy a gyermekkori csuklótörések ellátásában a RTG-vizsgálat felesleges, hanem azt, hogy tapasztalataink alapján az UH-vizsgálat nagyon effektív, hasznos kiegészítője lehet a napi ambuláns ellátásnak, illetve bizonyos feltételek teljesülése esetén a röntgenvizsgálat alternatívája is lehet.

A diagnosztikai módszer esetleges önálló alkalmazása, illetve kiterjesztése ugyanakkor számos jogi és gyakorlati kérdést is felvet (mikor, milyen dokumentácó szükséges az objektív értékeléshez, milyen képesítéssel lehetne végezni stb.), amelyek megválaszolása, illetve a megfelelő protokollok kidolgozása még várat magára. A szerzők további prospektív vizsgálatokat terveznek ezek eldöntésére.

Anyagi támogatás: A kézirat megírása anyagi támogatásban nem részesült.

Szerzői munkamegosztás: V. M.: A hipotézis kidolgozása, a vizsgálat lefolytatása, a kézirat elkészítése. J. G.: A vizsgálat lefolytatása, a kézirat elkészítése. B. Zs., K. E.,
G. N., K. D.: A vizsgálat lefolytatása. A cikk végleges változatát valamennyi szerző elolvasta és jóváhagyta.

Érdekeltségek: A szerzőknek nincsenek érdekeltségeik.

\section{Irodalom}

[1] Naranje SM, Erali RA, Warner, WC Jr, et al. Epidemiology of pediatric fractures presenting to emergency departments in the United States. J Pediatr Orthop. 2016; 36: e45-e48.

[2] Shah NS, Buzas D, Zinberg EM. Epidemiologic dynamics contributing to pediatric wrist fractures in the United States. Hand (NY) 2015; 10: 266-271.

[3] de Putter CE, van Beeck EF, Looman CW, et al. Trends in wrist fractures in children and adolescents, 1997-2009. J Hand Surg Am. 2011; 36: 1810-1815.e2

[4] Gornitzky AL, Milby AH, Gunderson MA, et al. Referral patterns of emergent pediatric hand injury transfers to a tertiary care center. Orthopedics 2016; 39: e333-e339.

[5] Slaar A, Walenkamp MM, Bentohami A, et al. A clinical decision rule for the use of plain radiography in children after acute wrist injury: development and external validation of the Amsterdam Pediatric Wrist Rules. Pediatr Radiol. 2016; 46: 50-60.

[6] Herren C, Sobottke R, Ringe MJ, et al. Ultrasound-guided diagnosis of fractures of the distal forearm in children. Orthop Traumatol Surg Res. 2015; 101: 501-505.

[7] Little JT, Klionsky NB, Chaturvedi A, et al. Pediatric distal forearm and wrist injury: an imaging review. Radiographics 2014; 34: $472-490$

[8] Dubrovsky AS, Kempinska A, Bank I, et al. Accuracy of ultrasonography for determining successful realignment of pediatric forearm fractures. Ann Emerg Med. 2015; 65: 260-265.

[9] Eckert K, Ackermann O. Sonographic fracture diagnosis in children. Unfallchirurg. 2014; 117: 355-368.

[10] Chaar-Alvarez FM, Warkentine F, Cross K, et al. Bedside ultrasound diagnosis of nonangulated distal forearm fractures in the pediatric emergency department. Pediatr Emerg Care 2011; 27: 1027-1032.

[11] Patel DD, Blumberg, SM, Crain, EF. The utility of bedside ultrasonography in identifying fractures and guiding fracture reduction in children. Pediatr Emerg Care 2009; 25: 221-225.

[12] Williamson D, Watura R, Cobby M. Ultrasound imaging of forearm fractures in children: a viable alternative? J Accid Emerg Med. 2000; 17: 2224.

[13] Chartier LB, Bosco L, Lapointe-Shaw L. Use of point-of-care ultrasound in long bone fractures: a systematic review and metaanalysis. CJEM 2017; 19: 131-142.

[14] Ruffing T, Danko T, Henzler T, et al. Number of positive radiographic findings in pediatric trauma patients. Emerg Radiol. 2017 Jan 26. doi: 10.1007/s10140-017-1482-x. [Epub ahead of print]

[15] Chia B, Kozin SH, Herman, MJ, et al. Complications of pediatric distal radius and forearm fractures. Instr Course Lect. 2015; 64: 499-507.

[16] Matheny JM, Brinker MR, Elliott MN, et al. Confidence of graduating family practice residents in their management of musculoskeletal conditions. Am J Orthop. 2000; 29: 945-952.

[17] Wellsh BM, Kuzma JM. Ultrasound-guided pediatric forearm fracture reductions in a resource-limited ED. Am J Emerg Med. $2016 ; 34: 40-44$.

[18] Ng L, Saul T, Lewiss RE. Sonographic baseline physeal plate width measurements in healthy, uninjured children. Pediatr Emerg Care 2014; 30: 871-874.

[19] Wong CE, Ang AS, Ng KC. Ultrasound as an aid for reduction of paediatric forearm fractures. Int J Emerg Med. 2008; 1: 267271.

(Varga Marcell dr., e-mail: drvmarcell@gmail.com) 